\title{
Editorial
}

\section{Saúde mental durante a pandemia COVID-19: escuta é imprescindível}

$\mathrm{E}$

m pouco mais de 12 meses, a COVID-19 espalhou-se, acumulando

153 milhóes de pessoas infectadas (no Brasil 21 milhóes) e mais de 4,5 milhóes mortas (no Brasil 600.000), até o momento.

A combinação de fatores como perdas, isolamento social e o esforço em processar um excesso de informaçóes levou à fadiga da pandemia caracterizada por crescente sofrimento psíquico. Prejuízos mentais e emocionais passaram a ser a maior preocupação em saúde, secundária, somente, à infecção viral. ${ }^{(1)}$ Estima-se que a recuperação desta pandemia, para adultos, ocorrerá entre 10 e 15 anos e que, entre um terço e a metade da população global venha apresentar sofrimento psíquico nos próximos anos.

Uma escuta ativa é fundamental para a conexão necessária quando se trata de saúde mental. A habilidade de escutar, como qualquer outra, precisa ser aprendida, praticada, aperfeiçoada. Profissionais de saúde, ainda que treinados para escutar, tendem a prescrever, tratar e educar mais do que praticar escuta atenta, sensível e empática. ${ }^{(2)}$ Enfermeiros, os principais responsáveis pelo cuidar, estão em posição privilegiada para exercer conduta dependente da escuta como ferramenta determinante na identificação de necessidades e no incentivo ao autocuidado.

Uma estratégia promissora baseada no uso da escuta para motivar pessoas a assumir responsabilidade sobre sua saúde e autocuidado é o coaching de saúde. É crescente o número de artigos relatando evidências de benefício clínico dessta abordagem. Em saúde mental, intervençôes de coaching de saúde têm sido associadas a redução de sintomas de estresse, ansiedade e depressão, aumento de resiliência, além de benefícios indiretos através da promoção de atividade física. ${ }^{(3)}$

Não existe a possibilidade de alcançar a subjetividade do outro sem escuta ativa, que vai além de ouvir o que é dito, pois implica em entrar em contato com o que não foi dito, ou seja, com as intençóes os sentimentos das pessoas. Ambos são grandemente expressos por comunicação não-verbal. Assim, uma escuta ativa implica em atenção e reflexão do ouvinte, além de uma observação cuidadosa de comportamento, propiciando uma avaliação de acurácia entre o que se ouve e o que se observa.

No contexto da pandemia, fatores inerentes às restriçôes sanitárias têm sido considerados quanto à escuta: o isolamento social, a comunicação remota por meio do uso da tecnologia - nem sempre disponível e limitada para a observação de comportamento, e ainda a importância das famílias para apoio e como fonte de conflitos. 
Considerada a gravidade deste cenário, a Universidade Federal de Sáo Paulo (UNIFESP) se vê imbuída de estudar a prevenção de prejuízos em saúde mental e traduzir seus achados na prática do cuidado. Nesse cenário, destacam-se algumas iniciativas discutidas no evento científico "Impacto da COVID-19 e as repercussóes na saúde mental de profissionais de saúde, indivíduos, família e comunidade", organizado pela Escola Paulista de Enfermagem (EPE), em agosto de 2020.

"Projeto Acolhimento COVID-19" de responsabilidade do Departamento de Psiquiatria da Escola Paulista de Medicina-EPM, da Disciplina de Enfermagem em Saúde Mental da Escola Paulista de Enfermagem-EPE e do Programa de Residência Multiprofissional em Saúde Mental UNIFESP. Neste projeto, dirigido a profissionais de saúde diretamente envolvidos com a assistência a pacientes com COVID-19, é oferecido aconselhamento interpessoal remoto, acessado por meio do endereço eletrônico do projeto. São coletados dados objetivos (escalas psicométricas), e subjetivos (observação). A partir de uma escuta inicial - com o intuito de definir razōes para sofrimento atual, identificar possibilidades de resolução e mecanismos de enfrentamento exitosos já experimentados - segue-se o atendimento em crise, com duraçáo limitada e acordos sobre as temáticas abordadas. Os atendimentos são discutidos remotamente pela equipe multiprofissional de assistência, docentes, enfermeiros, médicos psiquiatras, terapeutas ocupacionais e psicólogos, o consenso é então pactuado com os indivíduos para elaboração de projetos terapêuticos singulares. Casos com sintomatologia depressiva, comportamento suicida ou auto agressão são encaminhados para atendimento médico e psicoterapia. Observou-se que nos casos mais graves as queixas eram anteriores à COVID-19, e, portanto, não associadas somente à pandemia. Esta estrutura é baseada em abordagem que mostrou redução de tensōes e ansiedades, melhor organização do indivíduo, priorizaçáo e enfrentamento, e, melhora de autoestima e autoimagem dos atendidos e também dos profissionais envolvidos. ${ }^{(4)}$ Para que o impacto dessa estratégia seja positivo, a qualidade da escuta é fundamental.

"Acolhimento COVID-19 e luto de familiares por COVID-19 “ realizado pelo Grupo de Ensino e Pesquisa em Família e Comunidade (GEPFAC) e por ex-alunos do Curso de Terapia Familiar. Foram atendidos mais de 850 pessoas, incluindo profissionais de saúde, pessoas em sofrimento e familiares enlutados que trouxeram suas dificuldades e estratégias de enfrentamentos. De modo geral, falam da ansiedade, do medo de morrer, medo de se contaminar ou contaminar familiares, medo de voltar a trabalhar, irritação, raiva, insegurança, impotência, insônia, cansaço, perdas de pessoas queridas. A escuta ativa é usada para acolher falas sobre sentimentos, preocupaçōes e pensamentos, identificar o momento da crise com foco no presente, buscar estratégias e potencialidades, estimular o funcionamento independente e oferecer acompanhamento. Esse mesmo grupo propôs junto ao Ministério da Saúde atendimento à população, a partir da Terapia comunitária integrativa, que favoreceu o encontro de pessoas de várias localidades do Brasil para falarem dos seus incômodos e dificuldades na pandemia. Nos atendimentos, as queixas têm sido focadas em dificuldades nas relaçóes por conflitos familiares ampliados pela convivência ou pela 
separação provocadas pelo isolamento, ou pela violência aumentada nesse contexto. Todos refletiam dificuldades de comunicação e de gerenciamento do tempo. As principais estratégias e questôes dicutidas incluem pausas no trabalho (para descanso), atividade física, respiração, relaxamento, meditação, identificação de sintomas, limitação de notícias e busca por notícias confiáveis, substituição de pensamentos catastróficos por realistas e busca de suporte social. Depoimentos de avaliação desta estratégia têm enfatizado o impacto positivo sobre ansiedade e medo, ancorado na percepção de sentir-se acolhido e entendido, refletindo o valor da escuta sem julgamento. ${ }^{(5)}$

As iniciativas da EPE e da EPM Unifesp para minimizar o impacto da pandemia sobre a saúde mental corroboram o papel fundamental da escuta ativa no ato de cuidar. Os bons resultados obtidos podem ser potencializados pela capacitação para a prática da escuta ativa bem como para estratégias de coaching de saúde, favorecendo ainda mais desfechos positivos em saúde mental.

\section{Maria Carolina Braga Tuma \\ Professora Adjunta Visitante da Escola Paulista de Enfermagem, Universidade Federal de São Paulo, São Paulo, SP, Brasil. https://orcid.org/0000-0002-9046-3791}

Ana Lucia de Moraes Horta Professora Associada da Escola Paulista de Enfermagem, Universidade Federal de São Paulo, São Paulo, SP, Brasil. https://orcid.org/0000-0001-5643-3321

Maria Cristina Mazzaia Professora Associada da Escola Paulista de Enfermagem, Universidade Federal de São Paulo, São Paulo, SP, Brasil. https://orcid.org/0000-0001-5259-577X

Como citar:

Tuma MC, Horta AL, Mazzaia MC. Saúde mental durante a pandemia COVID-19: escuta é imprescindível [Editorial]. Acta Paul Enferm. 2021;34:e-EDT2.

DOI: http://dx.doi.org/10.37689/acta-ape/2021EDT00024

\section{Referências}

1. World Health Organization (WHO). Mental health and psychosocial considerations during COVID-19 outbreak. March, 2020. Genève: WHO; 2020. [cited 2021 Ma 31]. Available from: https://www.who.int/ docs/default-source/coronaviruse/mental-health-considerations.pdf 
2. Jahromi VK, Tabatabaee SS, Abdar ZE, Rajabi M. Active listening: The key of successful communication in hospital managers. Electron Physician. 2016;8(3):2123-8.

3. Sforzo GA, Kaye MP, Harenberg S, Costello K, Cobus-Kuo L, Rauff E, et al. Compendium of Health And Wellness Coaching: 2019 Addendum. Am J Lifestyle Med. 14(2):155-68.

4. Cruz AC, Pedreira ML. Patient-and family-centered care and patient safety: reflections upon emerging proximity. Rev Bras Enferm. 2020;73(6):e20190672.

5. Rente MA Melo, Merhy EE. Luto e não-violência em tempos de pandemia: precariedade, saúde mental e modos outros de viver. Psicol Soc. 2020;32:e020007. 